\title{
Comparison of Tube Thoracostomy and Thoracoscopic Debridement in the Treatment of Empyema in Children
}

\author{
Çocuklarda Ampiyem Tedavisinde Tüp Torakostomi ile Torakoskopik \\ Debridmanın Karşılaştırılması
}

\author{
낙alil İbrahim Tanrıverdi ${ }^{1}$
}

${ }^{1}$ Manisa Celal Bayar University Medical School, Department of Pediatric Surgery, Manisa, Turkey

\begin{abstract}
Objective: Empyema is an important problem that develops after pneumonia in children. Antibiotherapy and drainage of purulent fluid form the basis of treatment. Various methods are used for drainage. Thoracoscopic debridement is widely used today with the development of minimally invasive methods. In this study, patients who were treated for empyema in the period before the use of thoracoscopic debridement in our clinic were compared with the patients who were treated in the period after the use of thoracoscopic debridement.
\end{abstract}

Material and Method: For this purpose, cases before thoracoscopic debridement (Group 1, $\mathrm{n}=25$ ) and patients after thoracoscopic debridement (Group 2, $\mathrm{n}=28$ ) were compared in various aspects. While tube thoracostomy was applied to all cases in the first group, thoracoscopic debridement was applied to the cases in the second group whether or not tube thoracostomy was applied.

Results: Fever, leukocytosis, respiratory distress and purulent drainage lasted shorter in the group in which thoracoscopic debridement was applied, in other words, clinical improvement was faster. In the group in which thoracoscopic debridement was applied, the duration of tube thoracostomy was shorter and the need for thoracotomy was less than in the group not applied.

Conclusion: Thoracoscopic debridement accelerates the recovery of empyema in children. In this, it is effective to debride fibrin and septations in the pleural space more effectively and quickly under the camera view. Therefore, thoracoscopic debridement should be the first option in the treatment of empyema without delay.

Keywords: Empyema, Thoracoscopic debridement, Tube thoracostomy, children
ÖZ

Amaç: Ampiyem çocuklarda, pnömoni sonrası gelişen önemli bir sorundur. Antibiyoterapi ve pürülan sıvının drenajı tedavinin temelini oluşturur. Drenaj amacıyla çeşitli yöntemler kullanılır. Minimal invaziv yöntemlerin de gelişmesiyle günümüzde torakoskopik debridman yaygın olarak kullanılmaktadır. Bu çalışmada, kliniğimizde torakoskopik debridman kullanılmaya başlamadan önceki dönemde ampiyem nedeniyle tedavi edilen olgularla, torakoskopik debridman kullanılmaya başladıktan sonraki dönemde tedavi edilen olgular karşılaştırılmışlardır.

Gereç ve yöntem: Buamaçla kliniğimizde torakoskopik debridman öncesi olgular (Grup 1, n=25) ile torakoskopik debridman sonrası olgular (Grup 2, n=28) çeşitli yönleriyle karşılaştırılmışlardır. İlk gruptaki tüm olgulara tüp torakostomi uygulanırken, ikinci gruptaki olgulara öncesinde tüp torakostomi uygulansın ya da uygulanmasın torakoskopik debridman uygulanmıştır.

Bulgular: Torakoskopik debridman uygulanan grupta, uygulanmayan gruba göre ateş yüksekliği, lökositoz, solunum sıkıntısı ve pürülan drenaj daha kısa sürmüş, yani klinik iyileşme daha hızlı olmuştur. Torakoskopik debridman uygulanan grupta, uygulanmayan gruba göre tüp torakostomi süresi daha kısa, torakotomi ihtiyacı daha az saptanmıştır.

Sonuç: Torakoskopik debridman, çocuklarda ampiyemde iyileşmeyi hızlandırmaktadır. Bunda, plevral boşluktaki fibrin ve septasyonların kamera görüşü altında daha etkili ve hızlı debride edilmesi etkilidir. Bu nedenle ampiyem tedavisinde ilk seçenek zaman kaybetmeden torakoskopik debridman olmalıdır.

Anahtar kelimeler: Ampiyem, torakoskopi, debridman, tüp torakostomi, çocuk

Başvuru Tarihi/Received: 25.03.2021 Kabul Tarihi/Accepted: 11.06.2021
Corresponding Author: Halil İbrahim Tanriverdi
Address: Manisa Celal Bayar University Medical School, Department of Pediatric Surgery, Uncubozkoy, 45030, Yunusemre, Manisa, Turkey E-mail: halilibrahimtanriverdi@gmail.com 


\section{INTRODUCTION}

Empyema is an accumulation of purulent fluid in the pleural space. It occurs usually after pneumonia in children. Empyema develops in $2-8 \%$ of children hospitalized for pneumonia (1). Despite advances in diagnosis and treatment, empyema remains as an important cause of morbidity (2). While the incidence of pneumonia has decreased in children recently, the rate of parapneumonic effusion and empyema has risen (3). The conventional treatment of empyema involves drainage of fluid from the pleural space through tube thoracostomy. However, the success rate of tube thoracostomy alone is rather low in the presence of dense and loculated pleural fluid. Administration of fibrinolytic agents along with tube thoracostomy may also fail, especially in advanced stage empyema (4). With the development of minimally invasive methods, currently thoracoscopic debridement is widely used in empyema $(5,6,7,8)$. Owing to thoracoscopy, fibrin and septa can be successfully debrided by opening the loculated areas in the pleural space under direct vision.

In this study, the aim was to investigate the effects of thoracoscopic debridement on clinical improvement and duration of tube thoracostomy in the treatment of empyema in children. For this purpose, patients who were treated for empyema before the use of thoracoscopic debridement in our clinic were compared with those who were treated in the period after the use of thoracoscopic debridement started.

\section{MATERIAL AND METHOD}

Medical records of patients who were diagnosed with empyema and underwent tube thoracostomy or thoracoscopic debridement as the first treatment were retrospectively reviewed. The patients who were treated for empyema before 2001 when thoracoscopic debridement was implemented in our clinic (Group $1, n=25)$ were compared with those who received treatment in 2001 and after (Group 2, n=28) (53 cases in total). All empyema patients who underwent tube thoracostomy or thoracoscopic debridement as the first treatment were included in the study and no cases were excluded from the study.

\section{Treatment approach in empyema cases}

Patients suspected of empyema due to clinical and physical examination findings were evaluated by ultrasound and/or computed tomography scan in addition to chest $X$-rays. The investigation was directed to find out whether there was pleural fluid, pneumothorax, cavitation, loculation, atelectasis and pleural thickening in imaging methods. First, thoracentesis was performed and the characteristics of the fluid were evaluated. Cell count and type were evaluated by microscopic examination, and microorganisms were searched by gram staining. In the biochemical examination, $\mathrm{pH}$, protein, glucose and LDH values in the fluid were tested and simultaneously compared with the protein, glucose and LDH values in blood biochemistry. Furthermore, antibiotic susceptibility tests were performed for each culture on the collected fluids. Single, dual or multiple broad-spectrum antibiotherapy was administered to the patients depending on their clinical conditions and antibiogram results. Patients were followed up in the intensive care unit during the hospitalization, and were transferred to the ward when their clinical conditions were stable. Vital functions (body temperature, heart rate, blood pressure, respiratory rate and peripheral oxygen saturation) and fluid balance of the patients were monitored hourly in the intensive care unit and at appropriate intervals during their ward stay.

Tube thoracostomy was performed as the first step in treatment of all patients in the first group upon detection of fluid. In the second group, thoracoscopic debridement was performed without prior tube thoracostomy in the patients who had loculated or thick pleural fluid in the radiological examinations and/ or when no fluid could be removed by thoracentesis (in cases where fluid was observed radiologically but could not be removed by thoracentesis, it was assumed that the fluid was loculated and fibrinous). While tube thoracostomy was performed first in the other cases, thoracoscopic debridement was performed afterwards, since there was no clinical improvement. Patients in both groups were followed up with intermittent chest $X$-rays. The amount, characteristics of the drainage material and air outlet from the tube were recorded daily. Hematological and biochemical values of the patients were checked at certain intervals. Tube thoracostomies were terminated in the patients whose clinical and radiological findings regressed (lung expansion, fluid and improvement in pneumothorax) and whose drainage from the tube ceased. Empyema of the patients was staged according to clinical, laboratory, radiological examination and operational findings.

\section{Thoracoscopic debridement}

Thoracoscopic debridement was performed under general anesthesia in the lateral decubitus position in all cases. During the procedure, $\mathrm{CO}_{2}$ gas at a pressure of $5-8 \mathrm{mmHg}$ was insufflated into the pleural space. A $5 \mathrm{~mm}$ trocar was placed on the area where the highest amount of fluid was found radiologically (usually the point where the $4^{\text {th }}$ and $6^{\text {th }}$ intercostal space intersected with the midaxillary line) and the pleural space was visualized with a $30^{\circ}, 5 \mathrm{~mm}$-telescope. In cases with thoracic tube inserted, the tube was pulled out and the tube tract was used for the entrance of the first trocar. Once a vision was achieved by making some dissection with the camera in the pleural space, the second and, 
if necessary, the third trocar ( 3 or $5 \mathrm{~mm}$ ) was placed depending on the localization of the loculated fluid and septa. Septations in the pleural cavity were dissected under direct vision using a 3 or $5-\mathrm{mm}$ endoscopic dissector, scissors and aspirator inserted through the trocars; purulent fluid was aspirated, and fibrin was debrided. Later, the pleural space was irrigated with isotonic fluid with the help of a sump drain inserted through one of the trocar holes. At the end of the procedure, an appropriately sized thorax tube was inserted through one of the trocar holes into the pleural space with the help of a camera.

\section{Statistical Analysis}

Statistical analysis was performed using SPSS 15.0 for Windows program. Chi-Square and Mann-Whitney tests were used to compare the groups. A $p$ value of $<0.05$ was considered statistically significant.

\section{RESULTS}

Therapeutic intervention was performed in 53 cases for treatment of empyema. The mean age of the patients was $4.6(1-17)$ years; the female/male ratio was $25 / 28$. There were 25 cases in Group 1, and 28 cases in Group 2. Pleural effusion was located in right side in 29 cases and in left side in 23 cases. Bilateral pleural effusion was present in one case. Pre-intervention clinical and laboratory findings, and empyema stages of both groups were compared. The results were presented in Table 1. It was seen that the data obtained were similar in both groups and no statistically significant difference was found.

Post-intervention clinical and laboratory findings, tube thoracostomy and hospital stay durations of both groups were compared. The results were presented in Table 2. The mean CRP value measured on the first day after the intervention, the incidence of bronchopleural fistula development, the number of patients who received blood transfusion, the length of stay in the intensive care unit, the length of hospital stay after the intervention, and the total length of hospital stay were similar in both groups. Apart from these, other data were found to be significantly lower in Group 2. Improvement in clinical findings such as fever, respiratory distress, and leukocytosis was significantly faster in Group 2. Furthermore, duration of thoracic tube was significantly shorter in Group 2. Although the length of hospital stay was shorter in Group 2, it was not statistically significant.

In group 2, thoracoscopic debridement was performed first in 20 patients who had a loculated or thick pleural fluid on radiological examinations and/ or had undergone a failed thoracentesis, without prior tube thoracostomy (in cases where fluid was observed radiologically but could not be removed by thoracentesis, the fluid was assumed to be loculated and fibrinous). Tube thoracostomy was performed in the other 8 cases first, and thoracoscopic debridement was performed when there was no clinical improvement. Thoracotomy was performed in 6 cases in Group 1 due to the lack of clinical and radiological improvement (due to persistence of clinical findings in 2 cases, and continuation of clinical findings and bronchopleural fistula in 4 cases). In Group 2, fistula repair was performed by thoracotomy upon the persistence of bronchopleural fistula despite clinical improvement in only 1 case. In addition, in 1 case in Group 2, the fistula was repaired by performing thoracoscopy for the second time as the bronchopleural fistula persisted. Clinical improvement was achieved in all other cases, and bronchopleural fistulas regressed spontaneously. All cases were discharged with healing, and no patient died.

\begin{tabular}{|c|c|c|c|}
\hline & Group $1(n=25)$ & Group $2(n=28)$ & $\mathbf{p}$ \\
\hline Duration of complaints (mean \pm SD) (day) & $11.2 \pm 6.08$ & $11.21 \pm 6.82$ & 0.82 \\
\hline High fever at first admission ( $n$ ) & 21 & 19 & 0.21 \\
\hline Leukocyte count at first admission (mean \pm SD) $\left(/ \mathrm{mm}^{3}\right)$ & $21768.18 \pm 11376.51$ & $16747.69 \pm 8245.62$ & 0.11 \\
\hline CRP value at first admission (mean \pm SD) (mg/dl) & $16.38 \pm 12.1$ & $19.46 \pm 8.12$ & 0.57 \\
\hline Pleural LDH (mean \pm SD) $(\mathrm{U} / \mathrm{L})$ & $7462.62 \pm 10043.03$ & $4810.84 \pm 9765.95$ & 0.29 \\
\hline Pleural Protein (mean $\pm S D$ ) $(g / L)$ & $4.43 \pm 0.75$ & $4.57 \pm 1.34$ & 0.73 \\
\hline Serum LDH (mean \pm SD) (U/L) & $831.33 \pm 814.58$ & $879 \pm 495.94$ & 0.30 \\
\hline Serum Protein (mean $\pm S D$ ) $(g / L)$ & $6.06 \pm 0.61$ & $6.04 \pm 1.26$ & 0.51 \\
\hline Stage 1 empyema $(n)$ & 0 & 0 & - \\
\hline Stage 2 empyema ( $\mathrm{n}$ ) & 21 & 25 & 0.69 \\
\hline Stage 3 empyema ( $\mathrm{n}$ ) & 4 & 3 & 0.69 \\
\hline Cavitation (n) & 6 & 6 & 0.82 \\
\hline Number of antibiotics used per patient (mean \pm SD) & $2.52 \pm 0.77$ & $2.21 \pm 0.56$ & 0.06 \\
\hline $\begin{array}{l}\text { Time from the onset of the complaint to tube thoracostomy (Group 1) } \\
\text { and thoracoscopy (Group 2) (mean } \pm \text { SD) (day) }\end{array}$ & $12.80 \pm 5.91$ & $14.86 \pm 7.95$ & 0.43 \\
\hline
\end{tabular}


Table 2. Post-intervention clinical and laboratory findings, tube thoracostomy and hospital stay durations of both groups

\begin{tabular}{|c|c|c|c|}
\hline & Grup $1(n=25)$ & Grup 2 (n=28) & $\mathbf{p}$ \\
\hline $\begin{array}{l}\text { The duration of fever reduction after tube thoracostomy (Group 1) and } \\
\text { thoracoscopy (Group 2) (mean } \pm \text { SD) (day) }\end{array}$ & $10.71 \pm 9.19$ & $2.05 \pm 1.12$ & $<0.0001$ \\
\hline $\begin{array}{l}\text { Respiratory distress and regression of oxygen demand after tube } \\
\text { thoracostomy (Group 1) and thoracoscopy (Group 2) (mean } \pm \text { SD) (day) }\end{array}$ & $4.29 \pm 3.09$ & $1.33 \pm 0.51$ & 0.01 \\
\hline $\begin{array}{l}\text { Leukocyte count on the 1st day after tube thoracostomy (Group 1) and } \\
\text { thoracoscopy (Group 2) (mean } \pm \text { SD) (/mm3) }\end{array}$ & $17821.74 \pm 12456.5$ & $10320.42 \pm 4736.51$ & 0.04 \\
\hline $\begin{array}{l}\text { CRP value on the 1st day after tube thoracostomy (Group 1) and } \\
\text { thoracoscopy (Group 2) (mean } \pm \text { SD) (mg/dl) }\end{array}$ & $8.75 \pm 6.54$ & $7.52 \pm 4.9$ & 0.84 \\
\hline Duration of purulent drainage from thoracic tube (mean $\pm \mathrm{SD}$ ) (day) & $9.36 \pm 9.42$ & $2.32 \pm 1.09$ & $<0.0001$ \\
\hline $\begin{array}{l}\text { The duration of thoracic tube withdrawal after tube thoracostomy } \\
\text { (Group 1) and thoracoscopy (Group 2) (mean } \pm \text { SD) (day) }\end{array}$ & $13.16 \pm 8.73$ & $5.79 \pm 4.95$ & $<0.0001$ \\
\hline Total duration of thoracic tube (mean $\pm S D$ ) (day) & $13.16 \pm 8.73$ & $7.82 \pm 7.1$ & 0.003 \\
\hline Bronchopleural fistula (n) & 7 & 6 & 0.75 \\
\hline Number of patients applied blood transfusion (n) & 6 & 11 & 0.23 \\
\hline Amount of blood given per kg of body weight (mean $\pm \mathrm{SD})(\mathrm{ml})$ & $29.24 \pm 12.99$ & $14.1 \pm 4.51$ & $<0.0001$ \\
\hline Thoracotomy $(n)$ & 6 & 1 & 0.043 \\
\hline Length of stay in intensive care (mean \pm SD) (day) & $5.72 \pm 4.33$ & $4.82 \pm 4.27$ & 0.22 \\
\hline $\begin{array}{l}\text { Length of stay in hospital after tube thoracostomy (Group 1) and } \\
\text { thoracoscopy (Group 2) (mean } \pm \text { SD) (day) }\end{array}$ & $15.08 \pm 9.89$ & $11.36 \pm 9.21$ & 0.11 \\
\hline $\begin{array}{l}\text { Duration between first admission to hospital and withdrawal of the } \\
\text { thoracic tube (mean } \pm S D) \text { (day) }\end{array}$ & $14.2 \pm 9$ & $8.75 \pm 6.91$ & 0.008 \\
\hline Total length of hospital stay (mean \pm SD) (day) & $16.68 \pm 10.08$ & $14.96 \pm 10.81$ & 0.44 \\
\hline
\end{tabular}

\section{DISCUSSION}

The primary objective in treatment of empyema is the treatment of infection with antibiotherapy and the evacuation of pleural fluid to ensure adequate lung reexpansion. Thoracentesis, tube thoracostomy, fibrinolytic therapy, thoracoscopic debridement, thoracotomy and decortication can be used for the treatment of empyema in children (9). However, there is no consensus on which treatment should be used and when. The stage of empyema, the condition of the involved lung, the presence of a bronchopleural fistula, and the clinical condition of the patient affect the treatment.

The conventional treatment of empyema involves drainage of the pleural space through tube thoracostomy. However, the success rate of tube thoracostomy alone is rather low in the presence of dense and loculated pleural fluid. Although there are cases where tube thoracostomy has been successful, long-term use of antibiotics, the need for repeated tube thoracostomy, and the need for a long hospital stay constitute significant disadvantages $(10,11)$. After tube thoracostomy, a second tube may be required in $15-40 \%$ of the cases, and conversion to thoracotomy for open decortication or lobectomy may be needed $(2,12)$. The most important reason for the failure of the treatment performed with tube thoracostomy is the presence of fluid that is too thick to drain from the tube and septations that allow only some of the fibrin-containing fluid. Thus, tube thoracostomy becomes ineffective, duration of tube and time for clinical recovery are prolonged. For such patients, thoracoscopic debridement is recommended as a treatment option to eliminate loculations in the pleural space and to remove fibrin and pus that are too thick to be drained from the thoracic tube $(2,10-14)$. By dissecting loculations with thoracoscopic debridement, gelatinous, organized pleural material and empyema fluid are evacuated, allowing the lung to re-expand.

Thoracoscopy was performed in 9 cases by Kern and Rogders for the first time in the treatment of empyema in children in 1993 and they reported that a rapid recovery was achieved (15). This procedure has been widely used in children since then $(2,7,8,11,13,14)$. Thoracoscopic debridement allows reconstruction of a single pleural cavity by debriding intrapleural loculations and membranous structures. Furthermore, the thorax tube is placed more easily and conveniently under the camera view. This enables a more successful drainage. Thoracoscopic debridement has a higher chance of success than tube thoracostomy alone and shortens the duration of treatment (6-8). Thoracoscopic debridement reduces the length of hospital stay, facilitates return to normal activity, reduces the need for repeated thoracentesis and tube thoracostomy, as well as pain and anxiety in the child; It is less invasive compared with thoracotomy, reduces the need for blood transfusion and analgesia, and provides a better cosmetic appearance $(2,11,12,14)$

Although fibrinolytic therapy has recently become popular in empyema, studies have shown that duration of tube thoracostomy and hospital stay times are shorter in thoracoscopic debridement compared to fibrinolytic therapy $(16,17)$. In tube thoracostomy or 
in intrapleural fibrinolytic therapy along with tube thoracostomy, the dissection of septations and cleaning of the pleura can take days, while thoracoscopy can be performed more effectively in a few hours. Therefore, the duration of clinical recovery and tube thoracostomy is shortened. Studies have shown that the success rates of thoracoscopy and fibrinolytic therapy in empyema are similar, and they do not have any superiority over each other (18-20). There was no difference between the two methods in terms of length of hospital stay time, duration of tube drainage, duration of fever, and need for analgesics and oxygen (18). Generally, the criticism on this subject argued that thoracoscopy is a highcost operation performed under general anesthesia. However, in practice, it should be accepted that tube thoracostomies are also performed under general anesthesia in the operating room and perioperative complications may occur. (17). In addition, it should be kept in mind that operation costs are lower and fibrinolytic therapy costs are higher in developing countries compared to developed countries. In cases where fibrinolytic therapy is unsuccessful, the cost and length of hospital stay increase with thoracoscopy. In a meta-analysis, it was found that thoracoscopy and fibrinolytic therapy in empyema had similar rates in terms of complications, and the number of repeated attempts in thoracoscopy and the length of postoperative hospital stay were shorter (17). Thoracoscopic debridement is recommended as the first-line treatment method, especially in advanced stage empyema (21).

Pre-intervention clinical and laboratory findings, and empyema stages of both groups were similar in both groups and no statistically significant difference was found. This indicates that both groups had similar homogenous characteristics and severity of empyema in both groups was similar. In terms of staging, no patients with Stage 1 empyema were found in either groups, while the number of patients with Stage 2 and Stage 3 empyema was similar. Thus, both groups could be compared in terms of the effectiveness of the treatment method applied. Incidence of cavitation, which is an indicator of parenchymal necrosis, was similar in both groups. Both groups were similar in terms of this finding, which indicates the severity of the underlying pneumonia.

Clinical recovery is faster in cases who underwent thoracoscopic debridement compared to tube thoracostomy, and patients return to their normal lives sooner $(6,15,22)$. In our study, post-procedure fever, leukocytosis, respiratory distress and duration of regression in oxygen need were shorter in the thoracoscopy group; that is, clinical improvement was faster in this group. After the procedure (tube thoracostomy in the first group, and after thoracoscopy in the second group) leukocyte values were also lower in the second group. With thoracoscopic debridement, purulent and infected material was removed from the body more effectively and rapidly, which reflected to the clinical course and fever, leukocytosis and respiratory distress were reduced more rapidly.

By dissecting the loculations with thoracoscopic debridement, gelatinous, organized pleural material and empyema fluid are evacuated, allowing the lung to re-expand (23). Thus, purulent drainage takes a short time. In our study, duration of the purulent fluid drainage time after the procedure (tube thoracostomy in the first group, and after thoracoscopy in the second group) was shorter in the second group. Fibrinoid structures and septations were removed more effectively with thoracoscopy. This indicates that thoracoscopic debridement is more effective in the drainage of empyema and achieves drainage in a short time. In the treatment of empyema, thoracoscopy is a safe and effective method that prevents the chest tube from staying for a long time (24). In our cases, duration of the tube thoracostomy after thoracoscopic debridement was shorter compared to the cases in the first group. Thoracoscopic debridement accelerated the drainage of empyema and tube thoracostomies were terminated in a shorter time.

Parenchymal necrosis leads to bronchopleural fistula, resulting in a prolonged stay of thoracic tube in the chest, it also causes the signs of infection to persists $(11,13,14)$. In our study, no significant difference was found in both groups in terms of bronchopleural fistula development. Bronchopleural fistula developed in all cases with cavitation, which is an indicator of parenchymal necrosis. The development of a bronchopleural fistula is related to the severity of the underlying parenchymal disease, regardless of the procedure. This indicates that the disease in both groups had similar severity and that the groups were comparable to each other.

After tube thoracostomy, a second tube may be required in $15-40 \%$ of the cases, and thoracotomy and lobectomy for decortication may be needed $(2,12)$. However, problems such as disruption of the integrity of the thorax due to a large incision, pain and prolonged recovery in the postoperative period, and unwanted cosmetic appearance may occur with thoracotomy (2). In our study, thoracotomy was performed in 6 patients who did not show clinical improvement in the first group, whereas in the second group only 1 patient required thoracotomy due to the persistence of bronchopleural fistula despite clinical improvement. The need for thoracotomy was significantly less common in the second group. Thoracoscopic debridement reduced the need for thoracotomy. This indicates that thoracoscopic debridement is effective and sufficient in the treatment of empyema. 
Thoracoscopic debridement reduces the need for blood transfusion compared to thoracotomy (14). While there was no difference between the number of cases requiring blood transfusion in both groups, the amount of blood transfused per $\mathrm{kg}$ of body weight was significantly higher in the first group. This indicates that there was a higher blood need for the cases in the first group. In the first group, the prolongation of the clinical improvement and therefore the persistence of the infection and the greater need for thoracotomy increased the need for blood transfusion.

When compared to other treatment methods, thoracoscopic debridement shortens the length of hospital stay $(2,12,15-17)$. In both groups, there was no significant difference in terms of the time interval from the procedures to discharge, the length of stay in the intensive care unit and the length of hospital stay. In the second group, when the patients who underwent tube thoracostomy before thoracoscopic debridement are removed, the length of stay in the intensive care unit is significantly shortened. In the second group, patients who underwent tube thoracostomy before thoracoscopic debridement and were monitored in the intensive care unit caused prolonged length of stay in the intensive care unit. When the time interval from hospitalization to the removal of the thoracic tubes was considered as the surgical recovery time, it was found to be shorter in the thoracoscopy group. Surgical recovery of empyema was faster in patients who underwent thoracoscopic debridement with or without tube thoracostomy. Purulent drainage regressed in a shorter time in the second group owing to thoracoscopy.

\section{CONCLUSION}

In our study, clinical recovery and tube thoracostomy was shorter in the thoracoscopic debridement group compared to the other group, and the need for thoracotomy was lower. Debridement of fibrin and septations in the pleural space more effectively and rapidly under the camera view helps to achieve this. Thoracoscopic debridement contrubutes recovery from empyema in children. Tube thoracostomy alone causes both slow clinical recovery and progression of the disease and consequently loss of time. Therefore, we think that thoracoscopic debridement should be the first choice in the treatment of empyema and no time should be lost with tube thoracostomy beforehand.

\section{Limitations}

This study performed retrospectively and number of patients is small.

\section{ETHICAL DECLARATIONS}

Ethics Committee Approval: In this research, the data before 2020 was used and the research was concluded before 2020. According to the Regulation on Clinical Researches published in the Official Gazette of the Republic of Turkey with the number 28617 dated 3 November 2015, the ethics committee approval was not obtained in accordance with the article "Retrospective studies are outside the scope of the regulation (article 2(2))". This study was prepared in accordance with the Law on Protection of Personal Data, by anonymizing patient data and in accordance with the 2013 Brazil revision of the Helsinki Declaration and guidelines for Good Clinical Practice.

Informed Consent: Because the study was designed retrospectively, no written informed consent form was obtained from patients.

Referee Evaluation Process: Externally peer-reviewed.

Conflict of Interest Statement: The authors have no conflicts of interest to declare.

Financial Disclosure: The authors declared that this study has received no financial support.

Author Contributions: All of the authors declare that they have all participated in the design, execution, and analysis of the paper, and that they have approved the final version.

\section{REFERENCES}

1. Tan TQ, Mason EO Jr, Wald ER, et al. Clinical characteristics of children with complicated pneumonia caused by Streptococcus pneumonia. Pediatrics. 2002; 110:1-6.

2. Kercher KW, Attori RJ, Hoover D, et al. Thorascopic decortication as first-line therapy for pediatric parapneumonic empyema, a case series. Chest. 2000; 118:24-27.

3. Jaffe $A$, Calder AD, Owens $C M$, et al. Role of routine computed tomography in paediatric pleural empyema. Thorax. 2008; 63:897-902.

4. Ulku R, Onen A, Onat S, et al. Intrapleural fibrinolytic treatment of multiloculated pediatric empyemas. Pediatr Surg Int. 2004; 20:520-524.

5. Wurnig PN, Wittmer V, Pridun NS, et al. Video-assisted thoracic surgery for pleural empyema. Ann Thorac Surg. 2006; 81:309-313.

6. Kurt BA, Winterhalter KM, Connors $\mathrm{RH}$, et al. Therapy of parapneumonic effusions in children: Video assisted thoracoscopic surgery versus conventional thoracostomy drainage. Pediatrics. 2006; 118:e547-553.

7. Aziz A, Healey JM, Qureshi F, et al. Comparative Analysis of Chest Tube thoracostomy and video-assisted thoracoscopic surgery in empyema and parapneumonic effusion associated with pneumonia in children. Surg Infect. 2008; 9(3):317-323.

8. Schneider CR, Gaudere MWL, Blackhurst D, et al. Am Surg. 2010; 76(9):957-961.

9. Gates RL, Caniano DA, Hayes J, et al: Does VATS provide optimal treatment of empyema in children? A systematic review. J Pediatr Surg. 2004; 39(3):381-386.

10. Meier AH, Smith B, Raghavan A, et al. Rational treatment of empyema in children. Arch Surg. 2000; 135:907-912.

11. Rodriguez JA, Hill CB, Loe WA Jr, et al. Video-assisted thorascopic surgery for children with stage II empyema. Am Surg. 2000; 66:569-573.

12. Doski JJ, Lou D, Hicks BA, et al. Management of parapneumonic collections in infants and children. J Pediatr Surg. 2000; 35:265270. 
13. Rescorla FJ, West KW, Gingalewski CA, et al. Efficacy of primary and secondary video-assisted thoracic surgery in children. J Pediatr Surg. 2000; 35:134-138.

14. Subramaniam R, Joseph VT, Tan GM, et al. Experience with video-assisted thoracoscopic surgery in the management of complicated pneumonia in children. J Pediatr Surg. 2001; 36:316319.

15. Kern JA, Rodgers BM. Thoracoscopy in the management of empyema in children. J Pediatr Surg. 1993; 28:1128-1132.

16. Wait MA, Sharma $S$, Hohn J, et al. A randomized trial of empyma therapy. Chest. 1997; 111:1548-1551.

17. Pacilli M, Nataraja RM. Management of paediatric empyema by video-assisted thoracoscopic surgery (VATS) versus chest drain with fibrinolysis: Systematic review and meta-analysis. Paediatr Respir Rev. 2019; 30:42-48.

18. St. Peter SD, Tsao K, Harrison C, et al. Thoracoscopic decortication vs tube thoracostomy with fibrinolysis for empyema in children: a prospective, randomized trial. J Pediatr Surg. 2009; 44:106-111.

19. Mahant $S$, Cohen $E$, Weinstein $M$, et al. Video-assisted thorascopic surgery vs chest drain with fibrinolytics for the treatment of pleural empyema in children: a systematic review of randomized controlled trials. Arch Pediatr Adolesc Med. 2010; 164(2):201-203.

20. Islam S, Calkins CM, Goldin $A B$, et al. The diagnosis and management of empyema in children: a comprehensive review from the APSA Outcomes and Clinical Trials Committee. J Pediatr Surg. 2012; 47:2101-2110.

21. Scarci M, Abah U, Solli P, et al. EACTS expert consensus statement for surgical management of pleural empyema. Eur J Cardiothorac Surg. 2015; 48(5):642-653.

22. Coote N, Kay E, Coote N. Surgical versus non-surgical management of pleural empyema. Cochrane Database Syst Rev. 2005; CD001956.

23. Lawrence DR, Ohri SK, Moxon RE, et al. Thoracoscopic debridement of empyema thoracis. Ann Thorac Surg. 1997 64:144850.

24. Rodgers BM. Thorascopic procedures in children. Semin Pediatr Surg. 1993; 2:182-189. 